\title{
Effect of Different Bio-extracts on Shelf Life and Physical Parameters of Papaya (Carica papaya L.) cv. Red Lady
}

\author{
K. Sharvani ${ }^{1 *}$, K. Vanajalatha ${ }^{2}$, Veena Joshi $^{3}$ and S. Praneeth Kumar ${ }^{4}$ \\ ${ }^{1}$ Department of Fruit Science, College of Horticulture, Rajendranagar, \\ Hyderabad, Telangana, India \\ ${ }^{2}$ Sri Konda Laxman Telangana State Horticultural University, Mulugu, Siddipet, \\ Telangana, India \\ ${ }^{3}$ Department of Fruit Science, College of Horticulture, Mojerla, Wanaparthy, \\ Telangana, India \\ ${ }^{4}$ Department of Plant Physiology, Floricultural Research Station, Rajendranagar, \\ Hyderabad Telangana, India \\ *Corresponding author
}

\section{A B S T R A C T}

\section{Keywords}

Papaya cv. Red Lady, Bio-extracts,

Neem leaf extract, Physical parameters, Shelf life

Article Info

Accepted:

20 January 2021

Available Online:

10 February 2021
The research entitled "Effect of different bio-extracts on shelf life and physical parameters of papaya (Carica papaya L.) cv. Red Lady" was conducted at College of Horticulture, Rajendranagar, Hyderabad during the year 2019-2020. In the experiment, the design followed was Completely Randomized Design with three replications. The papaya fruits cv. Red Lady were coated with different bio-extracts i.e., $\mathrm{T}_{1}$ : Aloe vera gel extract- $20 \%$, $\mathrm{T}_{2}$ : Neem leaf extract- 20\%, $\mathrm{T}_{3}$ : Garlic extract- 10\%, $\mathrm{T}_{4}$ : Ginger extract- $20 \%, \mathrm{~T}_{5}:$ Guar gum $-1.5 \%, \mathrm{~T}_{6}$ : Acacia gum- $10 \%, \mathrm{~T}_{7}$ was taken as control and stored at ambient temperature. Fruits treated with neem leaf extract $20 \%\left(\mathrm{~T}_{2}\right)$ recorded significantly lowest PLW (11.14\%), ripening (93.33\%), spoilage (42.22\%) and significantly highest fruit firmness with peel $\left(1.23 \mathrm{~kg} / \mathrm{cm}^{2}\right)$ and fruit firmness without peel $\left(0.93 \mathrm{~kg} / \mathrm{cm}^{2}\right)$ at the end of storage. The highest shelf life (14 days) was observed in fruits treated with neem leaf extract $20 \%\left(\mathrm{~T}_{2}\right)$ followed by garlic extract $10 \%\left(\mathrm{~T}_{3}\right)$ (12.67 days). Hence, the research findings concluded that neem leaf extract $20 \%\left(\mathrm{~T}_{2}\right)$ found to be best in increasing the shelf life and improving the physical parameters of papaya cv. Red Lady fruits at ambient temperature.

\section{Introduction}

Papaya (Carica papaya L.) belongs to the family Caricaceae, a native fruit of Tropical America, is a very popular and an economically significant fruit crop in many tropical and subtropical countries. Papaya is a short-lived, succulent, evergreen tree that bears papaya fruits throughout the year (Paltati and Kumar, 2016). Papaya is considered one of the most important fruits worldwide because of its high contents of 
ascorbic acid $(60.9 \mathrm{mg})$, Vitamin A (0.047 $\mathrm{mg})$ and calcium $(20 \mathrm{mg}$ ) per $100 \mathrm{gm}$ of fruit pulp. A single $100 \mathrm{~g}$ serving of papaya would be sufficient to cover the daily nutritional requirements for one person (Rajasekhar Pinnamaneni, 2017). Every part of papaya plant is said to have medicinal value. It has wide consumption owing to its pharmacological properties and can be used as folk remedy for various disorders (Jurandi et al., 2011).

The perishable nature of papaya is a major drawback during storage and distant transportation. Papaya fruits are very susceptible to moisture loss and many fungal diseases causing enormous loss in fruit quality. Reports claim that about $30-50 \%$ of the harvested papaya never reach the consumers mainly due to postharvest spoilage (Mondal and Bose, 2007).

There are several methods for postharvest quality retention, but most of them are chemical based and thus pose health concerns owing to their residual toxicity, environmental pollution and their side effects on human health. Healthy and eco-friendly technologies are very popular. Natural plant extracts that are non-hazardous to both human health and environment are better alternatives to chemicals. Extracts obtained from plants have recently gained popularity and scientific interest for their antibacterial and antifungal activity (Santas et al., 2010). Polysaccharides have been extensively used in edible coating. These coatings have greater ability to reduce the water loss and gaseous exchange. They also delay ripening and senescence. They are extracted from various plant species. Crystalline property of some polysaccharides causes the cross linkage to form a better coating. Cellulose, starch, gums, and chitosan are the most commonly used polysaccharide materials (Prasad et al., 2018).

\section{Materials and Methods}

The experiment was conducted at PG Laboratory, College of Horticulture, Rajendranagar, Hyderabad during the year 2019-2020. The design adopted for the experiment was completely randomized design (CRD), with 7 treatments each having 3 replicates as per the procedure out lined by Panse and Sukhatme (1967).

Mature fruits of papaya cv. Red Lady as judged by presence of green colour with beginning of yellow bands of uniform size, free from diseases and injuries were selected and procured from a private orchard. Prior to the post-harvest treatment, the fruits were washed in potable water and then allowed to dry in shade. Then the fruits were subjected to edible bio-extract coating of following treatments: $\mathrm{T}_{1}$ - Aloe vera gel extract $(20 \%)$, $\mathrm{T}_{2}$ - Neem leaf extract (20\%), $\mathrm{T}_{3}-$ Garlic extract (10\%), $\mathrm{T}_{4}$ - Ginger extract (20\%), $\mathrm{T}_{5}$ Guar gum (1.5\%), $\mathrm{T}_{6}$-Acacia gum (10\%), $\mathrm{T}_{7}$ was taken as control and stored at ambient temperature.

The fresh fruits were dipped in the coating solutions at room temperature for $5 \mathrm{~min}$. At regular intervals, the fruits were rotated to increase the coating efficiency. They were allowed to drain for $2 \mathrm{~min}$ and then dried at room temperature.

\section{Preparation of bio-extract coating solutions}

Aqueous extracts of different bio-extract coatings i.e., Aloe vera gel extract $(20 \%)$ and Neem leaf extract (20\%), Garlic extract (10\%) and Ginger extract (20\%), Guar gum (1.5\%), Acacia gum $(10 \%)$ are prepared under laboratory conditions on percent weight basis by following the methods of Palei and Dash (2017), Singh and Majumdar (2001), Wijewardane et al., (2013) and Khaliq et al., (2015) respectively. 
Observations regarding physical parameters were recorded at 3 days interval during the storage period. Physiological loss in weight was determined by recording the initial weight of fruits on the day of initiating experiment and subsequently at three days interval. The loss of weight in relation to initial weight was calculated and expressed in percentage. Fruit firmness was measured with a penetrometer (Deccan Techno Corporation, 0-20 kg) equipped with a probe of $8 \mathrm{~mm}$ diameter and expressed in $\mathrm{kg} / \mathrm{cm}^{2}$. Fruit firmness without peel was measured manually using a penetrometer by dissecting each fruit vertically, each half placed on a table with the cut area facing up, and by pressing the plunger vertically into the flesh along the cut surface as followed by Azene et al., (2014). Ripening was measured by counting the number of fruits ripened and expressed in percentage. Spoilage was measured by counting the number of fruits spoiled and expressed in percentage. The spoilage of fruits was determined based on the visual observations like shrivelling, fungal infection, rotting, over ripening, splitting, browning and discolouration of fruits. The shelf life of fruits was determined by recording the number of days the fruits remained in good condition in storage. The stage where in more than 50 percent of the stored fruits became unfit for consumption was considered as end of shelf life in that particular treatment and expressed as mean number of days (Padmaja and Bosco, 2014).

\section{Results and Discussion}

\section{Physiological loss in weight (PLW)}

Data presented in Table 1 revealed that on $3^{\text {rd }}$ day of storage, significantly lowest PLW $(2.07 \%)$ was recorded in $\mathrm{T}_{2}$ (neem leaf extract $20 \%$ ) followed by $\mathrm{T}_{3}$ (garlic extract $10 \%$ ) $(2.82 \%)$ and the highest PLW was recorded in $\mathrm{T}_{7}$ i.e., control $(6.41 \%)$ at ambient temperature. On $12^{\text {th }}$ day of storage, significantly lowest PLW (11.14\%) was recorded in $\mathrm{T}_{2}$ (neem leaf extract $20 \%$ ), which could be due to its ability to retard moisture loss and senescence mechanism. The ability of neem leaf extract to check the growth of microbes, responsible for rotting and high metabolic rate might be another probable reason behind its efficacy in reducing PLW. The reduced weight loss might also be due to the formation of thin layer of coating on surface of fruits that reduced the evapotranspiration and respiration rate in the treated fruits (Gupta and Jain, 2014). The result obtained in the present investigation was similar with the result obtained by Siddiqua $e t$ al., (2018) in banana.

\section{Firmness with peel}

On $3^{\text {rd }}$ day of storage, significantly highest fruit firmness with peel $\left(5.2 \mathrm{~kg} / \mathrm{cm}^{2}\right)$ was recorded in $\mathrm{T}_{2}$ (neem leaf extract 20\%), followed by $\mathrm{T}_{3}$ (garlic extract $\left.10 \%\right)(5.03 \mathrm{~kg} /$ $\mathrm{cm}^{2}$ ) and lowest firmness with peel was recorded in $\mathrm{T}_{7}\left(2.83 \mathrm{~kg} / \mathrm{cm}^{2}\right)$ i.e., control fruits at ambient temperature as indicated by data presented in the Table 2. On $12^{\text {th }}$ day of storage, significantly highest firmness with peel $\left(1.23 \mathrm{~kg} / \mathrm{cm}^{2}\right.$ ) was recorded in $\mathrm{T}_{2}$ (neem leaf extract $20 \%$ ) treated fruits which may be due to the effect of azadirachtin on pectin molecules (Chauhan et al., 2012). The result obtained in the present investigation was in accordance with the findings obtained by Kalio et al., (2019) in mango.

\section{Firmness without peel}

Data presented in the Table 3 revealed that on $3^{\text {rd }}$ day of storage, significantly highest fruit firmness without peel $\left(4.73 \mathrm{~kg} / \mathrm{cm}^{2}\right)$ was recorded in $\mathrm{T}_{2}$ (neem leaf extract $20 \%$ ), followed by $\mathrm{T}_{3}$ (garlic extract $\left.10 \%\right)(4.43 \mathrm{~kg} /$ $\mathrm{cm}^{2}$ ) and lowest firmness without peel was recorded in $\mathrm{T}_{7}\left(2.27 \mathrm{~kg} / \mathrm{cm}^{2}\right)$ i.e., in control 
fruits treated fruits at ambient temperature. On $12^{\text {th }}$ day of storage, significantly highest firmness without peel $\left(0.93 \mathrm{~kg} / \mathrm{cm}^{2}\right)$ was recorded in $\mathrm{T}_{2}$ (neem leaf extract $20 \%$ ) treated fruits at ambient temperature.

In the present study, the firmness of fruits declined with progressive increase in storage period irrespective of treatment given to fruits. This was due to softening of fruits with the progress in storage time which could be due to texture modification through degradation of polysaccharides such as pectins, cellulose and hemicellulose that takes place during ripening (Shabina et al., 2019). Fruits treated with neem leaf extract 20\% showed higher firmness, which may be due to the effect of azardiractin on pectin molecules, delay in ripening and also on reduction of water loss (Chauhan et al., 2012). Similar result was obtained by Shrestha et al., (2018) in mango.

Table.1 Effect of bio-extracts on physiological loss in weight (\%) of papaya cv. Red Lady

\begin{tabular}{|l|c|c|c|c|}
\hline \multirow{2}{*}{\multicolumn{1}{|c|}{ Treatment }} & \multicolumn{4}{c|}{ PLW (\%) } \\
\cline { 2 - 5 } & \multicolumn{4}{|c|}{ Days after storage } \\
\cline { 2 - 5 } & $\mathbf{3}$ & $\mathbf{6}$ & $\mathbf{9}$ & $\mathbf{1 2}$ \\
\hline $\mathbf{T}_{\mathbf{1}}$-Aloe vera gel extract (20\%) & 3.63 & 6.34 & 10.21 & $*$ \\
\hline $\mathbf{T}_{\mathbf{2}}$ - Neem leaf extract (20\%) & 2.07 & 4.43 & 8.53 & 11.14 \\
\hline $\mathbf{T}_{\mathbf{3}}$ - Garlic extract (10\%) & 2.82 & 5.62 & 9.42 & 12.27 \\
\hline $\mathbf{T}_{\mathbf{4}}$ - Ginger extract (20\%) & 4.23 & 6.82 & 10.71 & $*$ \\
\hline $\mathbf{T}_{\mathbf{5}}$ - Guar gum extract (1.5\%) & 5.39 & 7.21 & 11.62 & $*$ \\
\hline $\mathbf{T}_{\mathbf{6}}$ - Acacia gum extract (10\%) & 5.63 & 7.89 & 12.31 & $*$ \\
\hline $\mathbf{T}_{\mathbf{7}}$ - Control & 6.41 & 11.21 & $*$ & $*$ \\
\hline Mean & 4.31 & 7.07 & 10.46 & 11.70 \\
\hline S.Em $\mathbf{\text { . }}$ & 0.019 & 0.018 & 0.016 & 0.031 \\
\hline CD at 5\% & 0.059 & 0.055 & 0.049 & 0.096 \\
\hline
\end{tabular}

*End of shelf life

Table.2 Effect of bio-extracts on fruit firmness with peel $\left(\mathrm{kg} / \mathrm{cm}^{2}\right)$ of papaya $\mathrm{cv}$. Red Lady

\begin{tabular}{|c|c|c|c|c|}
\hline \multirow[t]{3}{*}{ Treatment } & \multicolumn{4}{|c|}{ Firmness with peel $\left(\mathrm{kg} / \mathrm{cm}^{2}\right)$} \\
\hline & \multicolumn{4}{|c|}{ Days after storage } \\
\hline & 3 & 6 & 9 & 12 \\
\hline$T_{1}$-Aloe vera gel extract $(20 \%)$ & 4.43 & 2.77 & 1.43 & $*$ \\
\hline$T_{2}-$ Neem leaf extract $(20 \%)$ & 5.20 & 3.17 & 2.17 & 1.23 \\
\hline$T_{3}-$ Garlic extract $(10 \%)$ & 5.03 & 3.03 & 2.00 & 1.03 \\
\hline$T_{4}$ - Ginger extract (20\%) & 4.17 & 2.63 & 1.30 & * \\
\hline$T_{5}$ - Guar gum extract $(1.5 \%)$ & 3.93 & 2.37 & 1.17 & * \\
\hline$T_{6}-$ Acacia gum extract $(10 \%)$ & 3.77 & 2.13 & 1.03 & * \\
\hline $\mathbf{T}_{7}$ - Control & 2.83 & 1.13 & * & $*$ \\
\hline Mean & 4.19 & 2.46 & 1.52 & 1.13 \\
\hline S.Em \pm & 0.031 & 0.033 & 0.025 & 0.018 \\
\hline CD at $5 \%$ & 0.095 & 0.102 & 0.077 & 0.055 \\
\hline
\end{tabular}

*End of shelf life 
Table.3 Effect of bio-extracts on fruit firmness without peel $\left(\mathrm{kg} / \mathrm{cm}^{2}\right)$ of papaya $\mathrm{cv}$. Red Lady

\begin{tabular}{|l|c|c|c|c|}
\hline \multirow{2}{*}{\multicolumn{1}{|c|}{ Treatment }} & \multicolumn{4}{c|}{ Firmness without peel $\left(\mathbf{k g} / \mathbf{c m}^{2}\right)$} \\
\cline { 2 - 5 } & \multicolumn{4}{|c|}{ Days after storage } \\
\cline { 2 - 5 } & $\mathbf{3}$ & $\mathbf{6}$ & $\mathbf{9}$ & $\mathbf{1 2}$ \\
\hline $\mathbf{T}_{\mathbf{1}}$-Aloe vera gel extract (20\%) & 4.03 & 2.37 & 1.13 & $*$ \\
\hline $\mathbf{T}_{\mathbf{2}}$ - Neem leaf extract (20\%) & 4.73 & 2.77 & 1.77 & 0.93 \\
\hline $\mathbf{T}_{\mathbf{3}}$ - Garlic extract (10\%) & 4.43 & 2.47 & 1.53 & 0.77 \\
\hline $\mathbf{T}_{\mathbf{4}}$ - Ginger extract (20\%) & 3.77 & 2.23 & 0.87 & $*$ \\
\hline $\mathbf{T}_{\mathbf{5}}$ - Guar gum extract (1.5\%) & 3.43 & 2.03 & 0.73 & $*$ \\
\hline $\mathbf{T}_{\mathbf{6}}$ - Acacia gum extract (10\%) & 3.27 & 1.67 & 0.67 & $*$ \\
\hline $\mathbf{T}_{\mathbf{7}}$ - Control & 2.27 & 0.63 & $*$ & $*$ \\
\hline Mean & 3.70 & 2.02 & 1.12 & 0.85 \\
\hline S.Em \pm & 0.033 & 0.033 & 0.031 & 0.018 \\
\hline CD at 5\% & 0.102 & 0.102 & 0.095 & 0.055 \\
\hline
\end{tabular}

*End of shelf life

Table.4 Effect of bio-extracts on ripening (\%) of papaya cv. Red Lady

\begin{tabular}{|l|c|c|c|c|}
\hline \multirow{2}{*}{\multicolumn{1}{|c|}{ Treatment }} & \multicolumn{4}{c|}{ Ripening percentage (\%) } \\
\cline { 2 - 5 } & \multicolumn{4}{|c|}{ Days after storage } \\
\cline { 2 - 5 } & $\mathbf{3}$ & $\mathbf{6}$ & $\mathbf{9}$ & $\mathbf{1 2}$ \\
\hline $\mathbf{T}_{\mathbf{1}}$-Aloe vera gel extract (20\%) & 20.00 & 43.33 & 91.11 & $*$ \\
\hline $\mathbf{T}_{\mathbf{2}}$ - Neem leaf extract (20\%) & 6.67 & 20.00 & 44.45 & 93.33 \\
\hline $\mathbf{T}_{\mathbf{3}}$ - Garlic extract (10\%) & 13.33 & 26.67 & 48.89 & 97.78 \\
\hline $\mathbf{T}_{\mathbf{4}}$ - Ginger extract (20\%) & 26.67 & 43.33 & 93.33 & $*$ \\
\hline $\mathbf{T}_{\mathbf{5}}$ - Guar gum extract (1.5\%) & 28.89 & 46.67 & 95.55 & $*$ \\
\hline $\mathbf{T}_{\mathbf{6}}$ - Acacia gum extract (10\%) & 33.33 & 51.11 & 97.85 & $*$ \\
\hline $\mathbf{T}_{\mathbf{7}}$ - Control & 46.67 & 100.00 & $*$ & $*$ \\
\hline Mean & 25.08 & 47.30 & 78.53 & 95.55 \\
\hline S.Em \pm & 0.839 & 0.420 & 1.878 & 0.840 \\
\hline CD at 5\% & 2.570 & 1.285 & 5.753 & 2.574 \\
\hline
\end{tabular}

*End of shelf life

Table.5 Effect of bio-extracts on spoilage (\%) of papaya cv. Red Lady

\begin{tabular}{|l|c|c|c|c|}
\hline \multirow{2}{*}{\multicolumn{1}{|c|}{ Treatment }} & \multicolumn{4}{c|}{ Spoilage (\%) } \\
\cline { 2 - 5 } & \multicolumn{4}{|c|}{ Days after storage } \\
\cline { 2 - 5 } & $\mathbf{3}$ & $\mathbf{6}$ & $\mathbf{9}$ & $\mathbf{1 2}$ \\
\hline $\mathbf{T}_{\mathbf{1}}$-Aloe vera gel extract (20\%) & 0.00 & 20.00 & 42.22 & $*$ \\
\hline $\mathbf{T}_{\mathbf{2}}$ - Neem leaf extract (20\%) & 0.00 & 6.67 & 22.22 & 42.22 \\
\hline $\mathbf{T}_{\mathbf{3}}$ - Garlic extract (10\%) & 0.00 & 13.33 & 28.89 & 48.89 \\
\hline $\mathbf{T}_{\mathbf{4}}$ - Ginger extract (20\%) & 0.00 & 26.67 & 42.22 & $*$ \\
\hline $\mathbf{T}_{\mathbf{5}}$ - Guar gum extract (1.5\%) & 0.00 & 31.11 & 44.45 & $*$ \\
\hline $\mathbf{T}_{\mathbf{6}}$ - Acacia gum extract (10\%) & 0.00 & 33.33 & 46.67 & $*$ \\
\hline $\mathbf{T}_{\mathbf{7}}$ - Control & 0.00 & 46.67 & $*$ & $*$ \\
\hline Mean & 0.00 & 25.4 & 37.78 & 45.55 \\
\hline S.Em \pm & 0.00 & 0.839 & 1.878 & 1.188 \\
\hline CD at 5\% & 0.00 & 2.570 & 5.753 & 3.637 \\
\hline
\end{tabular}

*End of shelf life 
Table.6 Effect of bio-extracts on shelf life (days) of papaya cv. Red Lady

\begin{tabular}{|l|c|}
\hline \multicolumn{1}{|c|}{ Treatment } & Shelf life (days) \\
\hline $\mathbf{T}_{\mathbf{1}}$-Aloe vera gel extract (20\%) & 10.67 \\
\hline $\mathbf{T}_{\mathbf{2}}$ - Neem leaf extract $\mathbf{( 2 0 \% )}$ & 14.00 \\
\hline $\mathbf{T}_{\mathbf{3}}$ - Garlic extract $\mathbf{( 1 0 \% )}$ & 12.67 \\
\hline $\mathbf{T}_{\mathbf{4}}$ - Ginger extract $\mathbf{( 2 0 \% )}$ & 10.33 \\
\hline $\mathbf{T}_{\mathbf{5}}$ - Guar gum extract $\mathbf{( 1 . 5 \% )}$ & 9.33 \\
\hline $\mathbf{T}_{\mathbf{6}}$ - Acacia gum extract $\mathbf{( 1 0 \% )}$ & 9.00 \\
\hline $\mathbf{T}_{\mathbf{7}}$ - Control & 7.33 \\
\hline Mean & 10.47 \\
\hline S.Em \pm & 0.282 \\
\hline CD at 5\% & 0.863 \\
\hline
\end{tabular}

Fig.1 Effect of bio-extracts on shelf life (days) of papaya cv. Red Lady

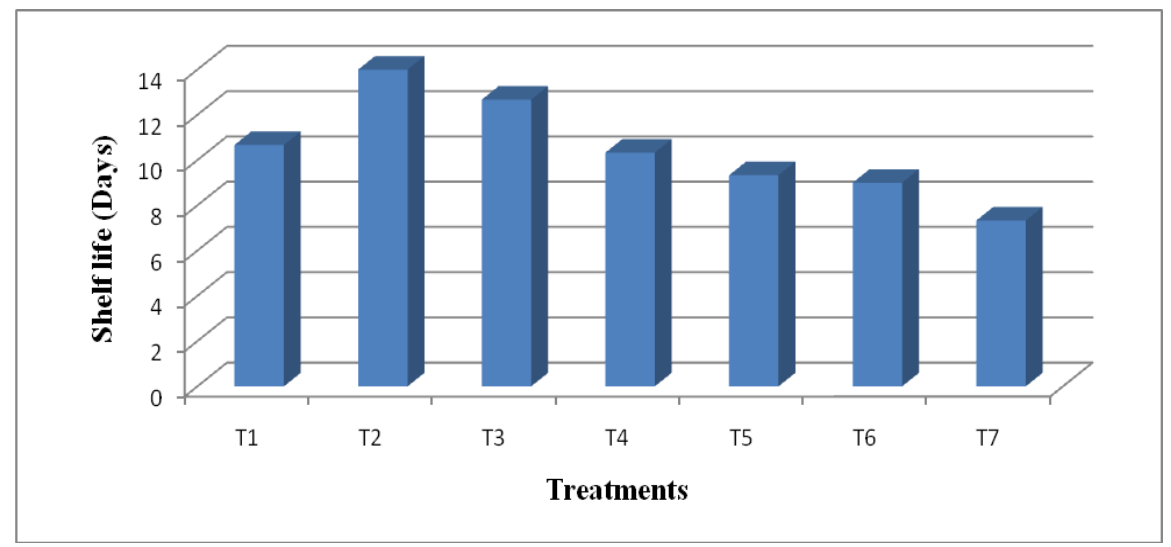

$\mathrm{T}_{1}$ - Aloe vera gel extract (20\%); $\mathrm{T}_{2}$ - Neem leaf extract (20\%); $\mathrm{T}_{3}-$ Garlic extract (10\%); $\mathrm{T}_{4}$ - Ginger extract (20\%); $\mathrm{T}_{5}$ - Guar gum extract (1.5\%); $\mathrm{T}_{6}$ - Acacia gum extract (10\%); $\mathrm{T}_{7}$-Control

\section{Ripening}

Data presented in Table 4 revealed that on $3^{\text {rd }}$ day of storage, significantly lowest ripening (6.67\%) was recorded in $\mathrm{T}_{2}$ (neem leaf extract $20 \%$ ), followed by $\mathrm{T}_{3}$ (garlic extract $10 \%$ ) $(13.33 \%)$ and the highest ripening $(46.67 \%)$ was recorded by $\mathrm{T}_{7}$ i.e., in control fruits at ambient temperature. On $12^{\text {th }}$ day of storage, significantly lowest ripening $(93.33 \%)$ was recorded in $\mathrm{T}_{2}$ (neem leaf extract $20 \%$ ) treated fruits which may be due to reduced respiration. The results are in accordance with the findings of Deshmukh et al., (2020) in Nagpur mandarins.

\section{Spoilage}

Spoilage was not recorded in both coated and uncoated fruits on $3^{\text {rd }}$ day of storage. On $6^{\text {th }}$ day of storage, significantly lowest spoilage $(6.67 \%)$ was recorded in $\mathrm{T}_{2}$ (neem leaf extract $20 \%$ ), followed by $\mathrm{T}_{3}$ (garlic extract $10 \%$ ) $(13.33 \%)$ and the highest spoilage was recorded in $\mathrm{T}_{7}$ (46.67\%) i.e., in control fruits at ambient temperature as indicated by data presented in Table 5. On $12^{\text {th }}$ day of storage, significantly lowest spoilage $(42.22 \%)$ was recorded in $\mathrm{T}_{2}$ (neem leaf extract 20\%) which may be attributed to the presence of principle compound azadiractin which has the ability to check the growth of pathogenic 
microorganisms that are responsible for rotting (Gupta and Jain, 2014). Similar result was obtained by Malik et al., (2015) in guava.

\section{Shelf Life}

Data presented in Table 6 and Figure 1 revealed that significantly highest shelf life (14 days) was recorded in $\mathrm{T}_{2}$ (neem leaf extract $20 \%$ ), followed by $\mathrm{T}_{3}$ (garlic extract 10\%) (12.67 days) and lowest shelf life (7.33 days) was recorded in $\mathrm{T}_{7}$ i.e., in control at ambient temperature. Highest shelf life seen in neem leaf extract $20 \%$ treated fruits at ambient temperature may be due to lowest PLW, ripening, spoilage percentage and higher firmness observed in neem leaf extract $20 \%$ treated fruits because of antifungal properties of neem preventing the microbial growth and its thin film reducing the evapotranspiration and respiration rate. The result obtained in the present investigation was in line with the findings obtained by Siddiqua et al., (2018) in banana.

Results of the experiment revealed that different bio- extract coatings significantly affected the shelf life and physical parameters of papaya cv. Red Lady fruit. Among the different bio-extract coatings, neem leaf extract $(20 \%)$ was best in terms of extending shelf life and maintaining physical parameters without causing adverse effects, followed by garlic extract (10\%) treatment.

\section{Acknowledgement}

We are thankful to Sri Konda Laxman Telangana State Horticultural University, for providing the laboratory facilities, technical support and financial assistance.

\section{References}

Azene, M., Workneh, T.S and Woldetsadik, K. 2014. Effect of packaging materials and storage environment on postharvest quality of papaya fruit. Journal of Food Science \& Technology. 51(6):10411055.

Chauhan, S.K., Thakur, K.S., Jawa, N.K and Thakur K.P. 2012. Botanical formulation and extracts based on plant leaves and flower, a substitute for toxic chemical and waxes for shelf life extension and quality retention of apple cv. Starking Delicious in India. Journal of Horticulture and Forestry. 4(12): 190200.

Deshmukh, S.D., Patil, S.R and Rajvaidya, R.R. 2020. Storage behavior of Nagpur mandarin fruits as affected by postharvest application of plant leaf extracts under cold storage condition. International Journal of Chemical Studies. 8(2): 877-880.

Gupta, N and Jain, S. K. 2014. Storage behavior of mango as affected by post harvest application of plant extracts and storage conditions. Journal of Food Science and Technology. 51(10): 24992507.

Jurandi, G.O and Angela, P.V. 2011. Papaya: Nutritional and pharmacological characterization, and quality loss due to physiological disorders. Food Research International. 44: 1306-1313.

Kalio, H., Okereke, F and Okereke, V. 2019. Comparison of polymeric films and plant materials in the preservation of Mango (Mangifera indica) Fruits. Research Journal of Food Science and Quality Control. 5 (1): 1-7.

Khaliq, G., Mohamed, M. T. M., Ali, A., Ding, $P$ and Ghazali, H. M. 2015. Effect of gum arabic coating combined with calcium chloride on physicochemical and qualitative properties of mango (Mangifera indica L.) fruit during low temperature storage. Scientia Horticulturae. 190: 187-194.

Malik, A.A., Bhat, A., Ahmed, N and Kaul, R. 
2015. Effect of postharvest application of plant extracts on physical parameters and shelf life of guava. Asian AgriHistory. 19 (3):185-193.

Mondal, M. F and Bose, S. K. 2007. Physicochemical changes in papaya fruits during storage. Journal Bangladesh Society of Agriculture Science Technology. 4 (3 \& 4): $145-148$.

Padmaja, N and Bosco, S.J. 2014. Preservation of Jujube fruits by edible aloe vera gel coating to maintain quality and safety. Indian Journal of Science Research and Technology. 2 (3): 79-88.

Palei, S and Dash, D.K. 2017. Influence of Post-Harvest Application of plant extracts and storage condition on postharvest physiology of mango cv. Amrapali. International Journal of Current Microbiology and Applied Sciences. 6 (8):1429-1440.

Paltati, A and Kumar, R.P.K. 2016. Carica papaya L. var. Taiwan red lady 786-An overview. Journal of Integral Sciences. 1 (4):1-12.

Panse,V.G and Sukhatme, P.V. 1967. Statistical methods for agricultural workers 2nd edition, ICAR, New Delhi.187-202.

Prasad, K., Guarav, A.K., Preethi, P and Neha, P. 2018. Edible coating technology for extending market life of horticultural produce. Acta Scientific Agriculture. 2:55-64.

Rajasekhar Pinnamaneni. 2017. Nutritional and medicinal value of papaya (Carica papaya Linn.). World Journal of
Pharmacy and Pharmaceutical Sciences. 6(8): 2559-2578.

Santas, J., Almajano, M.P and Carbo, R. 2010. Antimicrobial and antioxidant activity of crude onion (Allium cepa L.) extracts. International Journal of Food Science and Technology. 45 (2):403-409.

Shabina, N., Indu Rani, C., Auxcilia, J and Ganapathy, S. 2019. Enhancing the postharvest shelf life and quality of papaya fruits using different packaging materials and storage conditions. International Journal of Chemical Studies. 7 (3): 100-103.

Shrestha, S., Pandey, B and Mishra, B.P. 2018. Effects of different plant leaf extracts on postharvest life and quality of mango (Mangifera indica L.). International Journal of Environment, Agriculture and Biotechnology. 3 (2): 422-432.

Siddiqua, M., Ahmed, S., Khan, K.U., Tabassum, P and Sultana, S. 2018 Effects of neem leaf extract and hot water treatments on shelf life and quality of banana. Journal of Bangladesh Agricultural University. 16 (3): 351-356.

Singh, J and Majumdar, V.L. 2001. Efficacy of plant extracts against Alternaria alternata the incitant of fruit rots of pomegranate. Journal of Mycology and Plant Pathology. 31(3): 346-349.

Wijewardhane, R.M.N.A. 2013. Application of polysaccharide based composite film wax coating for shelf life extension of Guava (var. Bangkok Giant). Journal of Postharvest Technology. 1 (1): 16-21.

\section{How to cite this article:}

Sharvani, K., K. Vanajalatha, Veena Joshi and Praneeth Kumar, S. 2021. Effect of Different Bio-extracts on Shelf Life and Physical Parameters of Papaya (Carica papaya L.) cv. Red Lady. Int.J.Curr.Microbiol.App.Sci. 10(02): 2865-2872. doi: https://doi.org/10.20546/ijcmas.2021.1002.318 